\title{
Research article: Attitude of the scientists of Anand Agricultural University towards organizational climate
}

Article Chronicle:
Received :
23.07.2017;
Revised :
07.12.2017;
Accepted :
23.12.2017

Article Chronicle: Revised : 23.12.2017

\section{KEY WoRds:}

Scientists, Attitude, Significance, Organizational climate, Agricultural University
SUMMARY : The present study was conducted in the Anand Agricultural University, Anand of Gujarat state, by personally interviewing the proportionally selected 150 scientists engaged in teaching, research and extension activities. The attitude of the scientists towards organizational climate is not independent itself, but is rather a complex process which is governed by personal-economic, job related and psychological attributes. The data were collected by personal contacts. The data were classified, tabulated and analyzed in order to make the findings meaningful. The statistical measures, such as percentage, Karl Pearson's co-efficients of correlation were used to analysis data. It was observed from the study that slightly more than four-fifth $(82.67 \%)$ of the overall scientists engaged in teaching, research and extension education activity in the university had positive to highly positive attitude towards their organizational climate. The attitude of the scientists towards organizational climate was observed significantly related with their independent variables like age, experience, job involvement, job performance, job satisfaction, achievement motivation and attitude towards job. In other words it can be said that the level of attitude was found more positive among those scientists who had old age, more experience, high job involvement, high job performance, high job satisfaction, high achievement motivation and highly positive attitude towards job. The result of this study in terms of different personal-economic, job related and psychological characteristics of scientists in forming their attitude towards organizational climate would act as a guideline to the administrations or higher authority to plan, implementing programmes related to human resource development within the organization.

How to cite this article : Yunus, Mohmmad and Desai, C.P. (2018). Attitude of the scientists of Anand Agricultural University towards organizational climate. Agric. Update, 13(1): 18-23; DOI : 10.15740/HAS/AU/ 13.1/18-23.
Author for correspondence :

\section{Mohmmad Yunus}

Transfer of Technology and Social Sciences Division, Central Sheep and Wool Research Institute, Avikanagar, Malpura, Tonk (Rajasthan) India Email:mohmmad_yunus@ yahoo.com

See end of the article for authors' affiliations 